\title{
MODERN ENGLISH CLASSICAL SCIENTIFIC TERMINOLOGY
}

\author{
ELVIRA PÉREZ IGLESIAS \\ Universidad de Salamanca
}

\begin{abstract}
The main aim is to show the introduction of classical loanwords into the scientific terminology of Modern English due to the influence they exert in English as a result of the importance of Latin and Greek language, culture and literature, their extensive acceptance and their international nature. The high degree of specialization forces $18^{\text {th }} \mathrm{c}$. and $19^{\text {th }} \mathrm{c}$. scientists to acquire classical technical terms. These new words (concerning the division of science into new branches and their sub-branches, mathematics, physics and chemistry) are recorded in the literary language and in scientific and technical writings of this period.
\end{abstract}

Key words: Classical loanwords - scientific terminology - Modern English

\section{RESUMEN}

El objetivo principal es mostrar la introducción de préstamos clásicos en la terminología científica del Inglés Moderno debido a la influencia que ejercen en el inglés como resultado de la importancia de la lengua, cultura y literatura greco-latinas, su amplia aceptación y su carácter internacional. El alto grado de especialización obliga a los científicos de los siglos XVIII y XIX a adquirir tecnicismos clásicos. Estas nuevas palabras (sobre la división de la ciencia en nuevas ramas y sus sub-ramas, matemáticas, física y química) se registran por primera vez en la lengua literaria y en los escritos científico-técnicos de este perido.

Palabras clave: Préstamos clásicos - terminología científica - Inglés Moderno

The technical vocabulary introduced into English in the $18^{\text {th }} \mathrm{c}$. and $19^{\text {th }} \mathrm{c}$. is of varied origin: loanwords from other languages, adapted native terms, deliberate formations, blends and doublets (Vid. Pérez Iglesias, 1998: 361-88). Most loanwords are European (Classical, 
Romance, mainly French, Italian and Spanish, and Teutonic) as well as Asian. According to N. F. Blake (1996: 299), "English absorbed a huge number of foreign words during this period, partly because of the advance of science and technology, partly because of the development of new political ideals, and partly because of the colonisation of large parts of the globe”. As D. Crystal (2003: 126) states,

when one language takes lexemes from another, the new items are usually called loan words or borrowings -though neither term is really appropriate, as the receiving language does not give them back. English, perhaps more than any other language, is an insatiable borrower. Whereas the speakers of some languages take pains to exclude foreign words from their lexicons, English seems always to have welcomed them.

According to C. M. Millward (1996: 228), "borrowing was the easiest and most obvious way to fill the gaps in English vocabulary, and Latin was the easiest and most obvious language from which to borrow". The chief feature of classical loanwords is the constant influence they exert in English as a result of the importance of Latin and Greek language, culture and literature, their extensive acceptance and their international nature. As $\mathrm{S}$. Gramley and K. M. Pätzold (1992: 15) point out, "the two classical languages have provided English as well as most other (European) languages with countless technical terms in all branches of human knowledge".

Purists are opposed to the introduction of foreign words in English dictionaries, but their desire for controlling the "flood" of classical words is in vain. The new words have precise meanings and are exempt from distorting associations. A J. Culpeper (1997: 26) states, "Germanic words tend to be simple, often words of one syllable, whereas Latin words are usually polysyllabic".

The international scientific vocabulary is chiefly formed by means of agglutinated classical morphemes, e.g. Modern English dynamometer (1810: The Quarterly Review, August), French 'dynamometre', German 'Dynamometer', Swedish 'dynamometer'; Modern English interferometer (1899: Ld. Rayleigh in Nature), French 'interférometre', German 'Interferometer', Swedish 'interferometer'; or Modern English piezoelectric (1899: Nature, $6^{\text {th }}$ of July), French 'piézo-électrique', German 'piezoelektrisch', Swedish 'piezoelektrisk'. According to M. Görlach (1994: 151), "loanwords facilitate international communication (through shared terminologies in the sciences)". He thinks that "the stock of these words is, then, international. Although they tend to be pronounced (and sometimes spelt) according to national conventions, they are intelligible across language boundaries" (M. Görlach, 1999: 114).

Nevertheless, there are international words discarded in favour of native formations. In British English, aeroplane gives way to aircraft and French replaces 'aéroplane' by 'avion', German 'aeroplan' by 'Flugzeng' and Swedish 'aeroplan' by '(flyg)plan'. Indeed, "borrowing is the characteristic method whereby English expands its vocabulary, something which marks English off from its near relatives such as German" (Smith, 1999: 14). As N. F. Blake (1996: 22) emphasizes, "although some experimented with the use of Germanic words for science, scientists came to accept that it was best to use loans from Latin or Greek". 
As D. Crystal (2003: 372) recognizes, "first impressions of the language of science are that its distinctiveness lies in its lexicon". The most obvious influence of science on the English language is represented in the increase of scientific vocabulary. The high degree of specialization forces $18^{\text {th }}$ and $19^{\text {th }}$ century scientists to acquire technical terms of classical origin. The new words are recorded in the literary language and in the scientific and technical writings of this period. According to N. F. Blake (1996: 229), "the Latin loans tend to be bookish in nature because they form elements in a specialised vocabulary".

The modern point of view in the world of science is indicated by such words as scientist, first recorded in 1840, and specialist, in a general sense recorded in 1842, but as applied to medicine first recorded in 1856 . The nouns sciencer $\left(16^{\text {th }} \mathrm{c} .-17^{\text {th }} \mathrm{c}\right.$. $)$, scientiate $\left(17^{\text {th }} \mathrm{c}.\right)$, scientman $\left(17^{\text {th }} \mathrm{c}\right.$.) and sciencist $\left(18^{\text {th }} \mathrm{c}\right.$.) are replaced by scientist when Dr. Whewell invents this term in 1840, together with physicist, and he first used it in his Philosophy of the Inductive Sciences (1840).

Science is divided into fields and it is necessary to denote new branches and their subbranches, so that terminologies with Greek endings are formed, e.g. the nouns in -logy (through French and Latin, from Greek "logos", 'word, speech'), e.g. aerology ("that department of science which treats of the atmosphere', combining form from Greek "áer", 'air'. 1753: Chambers, Cyclopadia: Supplement), anemology ('the doctrine or science of the winds', from Greek “ánemos”, 'wind'. 1791: E. Darwin, The Botanic Garden), hydrology ('the science which treats of water, its properties and laws, its distribution over the earth's surface, etc.', from Latin "hydrologia”. 1762: translation of Busching's System of Georgia) and spectrology ('the science or study of spectres', combining form of Latin "spectrum", 'image'. 1820: W. Irving, The Sketch Book of Geoffrey Crayon). Most of these formations show Greek constituents, but there are hybrids with Latin and Greek elements and their number increases.

We may add the nouns in -ics (fom Latin “-icus”, which denotes 'ownership'), e.g. the noun physics, 'the science, or group of sciences, treating of the properties of matter and energy', is followed by physical sub-sciences formed by analogy, e.g. aeronautics ('the science, art, or practice of sailing in the air; aerial navigation', from Latin "aeronautica". 1753: Chambers, Cyclopadia: Supplement), electrostatics ("the science dealing with statical electricity', combining form of Greek “elektron”, 'amber'. 1885: Watson \& Burbury, The Mathematical Theory of Electricity and Magnetism), kinematics ('the science of pure motion, considered without reference to the matter or objects moved, or to the force producing or changing the motion', from Greek "kínema”, 'movement'. 1840: Whewell, Philosophy of the Inductive Sciences), and kinetics ('the branch of dynamics which investigates the relations between the motion of bodies and the forces acting upon them', from Greek "kínetikós”, from "kínein”, ‘to move'. 1864: Webster).

The new formations are produced by combining classical morphemes in order to obtain words appropriate for the needs of a scientist, who can easily infer the meaning of terms. According to M. Görlach (1999: 111), "these elements can be freely combined to form technical terms and are largely transparent to those who have a modicum of Greek". Thus, dynamics (from French "dynamique") includes, for instance, the following specialties: aerodynamics ('the branch of Pneumatics which treats of air and other gases in motion, and 
of their mechanical effects', combining form of Greek “áer", 'air'. 1837: The Popular Encyclopadia), electrodynamics ('the dynamics of electricity; the science of the mutual influence of electric currents', combining form of Greek "elektron”, 'amber'. 1830: Sir J. Herschel, A Preliminary Discourse on the Study of Natural Philosophy), hydrodynamics ('the branch of physics which treats of the forces acting upon or exerted by liquids', from Latin "hydrodynamica". 1779: Mann in Philosophical Transactions) and thermo-dynamics ('the theory of the relations between heat and mechanical energy, and of the conversion of either into the other', Present-day English thermodynamics, combining form of Greek "thermos", 'hot'. 1854: Philosophical Transactions).

Thus the neoclassical morphemes form numerous scientific terms. The great advances in a scientific field usually lead to an increase in lexicon, as in the case of the research on very low temperatures and their effects. Scientists form many new terms with the Greek morpheme "cryo-", 'frost, icy cold', e.g. cryogen ('a freezing-mixture, or a substance which when mixed with ice produces a freezing mixture'. 1875: F. Guthrie in Proceedings of the Physical Society), cryohydrate ('a solid hydrate formed by the combination of a salt or other crystalloid with water (ice) at a temperature below freezing-point'. 1874: F. Guthrie in Proceedings of the Physical Society), cryophorus ('an instrument for illustrating the freezing of water by evaporation'. 1826: W. Henry, The Elements of Experimental Chemistry), etc. As M. Görlach (1999: 111) states, "the coining of such words increased from the Renaissance onwards and had its first peaks with the development of the new sciences in the $17^{\text {th }}$ and $18^{\text {th }}$ centuries".

The development of scientific lexicon is mainly produced in mathematics, physics and chemistry. According to M. Görlach (1999: 114), "many of the neologisms hardly ever ocur outside specialist contexts".

In mathematical terminology, geometry vocabulary is extended with terms such as locus ('the curve or other figure constituted by all the points which satisfy a particular equation of relation between coordinates, or generated by a point, line, or surface moving in accordance with any mathematically defined conditions', from Latin "locus", 'a place'. 1715: G. Cheyne, Philosophical Principles of Natural Religion), pi ('Greek letter used in mathematics to express the ratio of the circumference or periphery of a circle to its diameter', from Greek "pi". 1748: Euler, Introduction in Analytical Infinitesimals) and trapezoid ('a quadrilateral figure no two of whose sides are parallel', from Latin “trapezoïdes”. 1704: J. Harris, Lexicon Technicum).

New algebraic terms are formed, e.g. sinh ('hyperbolic sine', from "hyperbolic sine", from Latin "hyperbolicus", 'or, belonging to, or of the form or nature of a hyperbola', and "sinus", 'bosom'. 1880: Encyclopadia Britannica), subgroup ('a subordinate group; a subdivision of a group', from Latin "sub-", 'under', and French "groupe”, 'a number of persons or things regarded as forming a unit on account of any kind of mutual or common relation'. 1888: Morrice, translation of Klein's Lecture on Ikosahedron), tensor ('in Quaternions, a quantity expressing the ratio in which the length of a vector is increased', from Latin "tensor". 1704: J. Harris, Lexicon Technicum) and vector ('a quantity having direction as well as magnitude, denoted by a line drawn from its original to its final position', from Latin “vector”. 1704: J. Harris, Lexicon Technicum). 
Other mathematical terms are haversine ('half the versed sine in Trigonometry', contraction of Old English "half", 'one of the two sides of an object', and translation of Latin "sinus versus", 'versed sine'. 1875: Bedford, Sailor's Pocket Book), maximum ('the greatest of all the values of which a variable or a function is capable', substantival use of the neuter of the adjective "maximus". 1743: Emerson, Fluxions), minimum ("minimum value of a function, its value when it ceases to decrease and begins to increase, as the value of the variable changes continuously', from Latin "minimum", neuter of the adjective "minimus". 1743: Emerson, Fluxions), quaternion ("the quotient of two vectors, or the operator which changes one vector into another', from Latin "quaternio". 1843: Sir W. R. Hamilton, Letter in The Philosophical Magazine), etc.

Some of the words from physics are applied to electricity, thermodynamics and optics. In electricity, we find, for instance, accumulator ('an apparatus or arrangement for collecting and storing electricity', from Latin “accumulator”. 1877: W. Thomson, Voyage of Challenger), anion ('the name given by Faraday to an electro-negative element, which in electro-chemical decompositions is evolved at the anode or positive pole of the battery', from Greek "anion”, present participle of the verb "aniénai”, 'to go up'. 1834: Faraday, Research in Electricity), anode ("the path by which an electric current leaves the positive pole, and enters the electrolyte, on its way to the negative pole', from Greek "ánodos" -“aná", 'way up', and "hodós", 'way'-. 1849: Russel and Woolrich in Orr's Circle of the Sciences), cable ('a rope-like line used for submarine telegraphs', from Latin "capulum”, 'a halter for catching or fastening cattle'. 1854: Specifications of Brett's Patent), cathode ('the path by which an electric current leaves the electrolyte and passes into the negative pole', from Greek "káthodos" -“katá", 'down', and "hodós”. 1834. Faraday, Research in Electricity), cation ('the name given by Faraday to an electro-positive element, which in electro-chemical decomposition is evolved at the cathode', from Greek "cation". 1834: Faraday, Research in Electricity), electrode ('one of the poles of a galvanic battery', from Latin "electricus" and Greek "hodós". 1834: Faraday, Research in Electricity), electrolyte ('a body which can be, or is being decomposed by electrolysis', from Greek "elektro-", combining form of "elektron", 'amber', and "lutós", 'loosened'. 1834: Faraday, Research in Electricity), insulator ('a body or substance that entirely or to a great degree prevents the passage of electricity or heat between contiguous bodies', agent noun, from Latin "insula", 'island'. 1801: Encyclopaedia Britannica), ion ("name given by Faraday to either of the elements which pass to the 'poles' or electrodes in electrolysis', from Greek "ion”, neuter present participle of the verb “iénai”, 'to go'. 1834: Faraday, Research in Electricity), etc.

As we can see, the English physicist and chemist Michael Faraday (1791-1867), one of the pioneers in the history of electricity, introduced into electro-chemistry most of its present terminology and was advised by the scientific theoretician William Whewell (17941866) to search for the cooperation of language specialists in order to give more accuracy to the lexicon that he was going to introduce.

In 1891 the Irish physicist George Stoney (1826-1911) suggested that 'the minimum electric charge' should receive the name of electron. When in the last years of that decade Thomson proved that cathodic rays are currents of particles and found out that each one 
carries the minimum quantity of negative electric charge of Stoney, the name electron was applied to the negative particle, not to the quantity of the charge. The unit of electric charge electron is derived from Latin "electr(ic)" and "-on", the ending of anion, cation and ion and was first recorded in English in Transactions of the Royal Dublin Society (1891).

Thermodynamics, which started in the $17^{\text {th }}$ c., used at the time terms such as calorimetry ('the measurement of heat', from Latin "calorem", 'heat', and Greek "-metría", 'measurement'. 1858: Lardner, Handbook of Natural Philosophy and Astronomy), entropy ('the name given to one of the quantitative elements which determine the thermodynamic condition of a portion of matter', from Greek 'tropé”, 'transformation'. 1868: Tait, Sketch of Thermodynamics), latent heat ('the heat required to convert a solid into liquid or vapour, or a liquid into vapour', from Latin "latentem", present participle of the verb "latere", "to be hidden', and Old English "hætu”, 'heat'. 1757: J. Black, Lectures), therme ('a proposed unit of heat', Present-day English therm, from Greek "thermós", 'hot'. 1888: Reports of the British Association) and thermostat ('an automatic apparatus for regulating temperature', from Greek "thermo-", combining form of "thermós", and "statós", 'standing". 1831: Ure in Proceedings of the Royal Society).

In optics there are words such as allotropy ("the variation of physical properties without change of substance to which certain elementary bodies are liable', from Greek "allotropía". 1850: Ansted, Elementary Course of Geology, etc.), chromatic ('pertaining to colour', from Latin "chromaticus". 1841-44: R. Emerson, Essays) and photometria ("measurement of light', Present-day English photometry, from Latin "photometria". 1760: Lambert, Photometria).

The French chemist Lavoisier actively took part in the formation of scientific terminology because he was the secretary of a committee that the French revolutionary government constituted in 1790 in order to reform the French system of weights and measurements (the British scientists accepted the French reform of chemical terminology). The result of this is the metric system, now international, where Latin and Greek roots are used and fractions of the metric units are introduced into English, using words with Latin roots (e.g. decimeter, Present-day English decimeter (US), -re (Brit); centimetre, Presentday English centimetre (Brit), -er (US); millimeter, Present-day English millimeter(US), -re (Brit), etc.) and the multiples are Greek (e.g. decameter, Present-day English decameter (US), -re (Brit); hectometer, Present-day English hectometer (US), -re (Brit); kilometer, Present-day English kilometer (US), -re, (Brit), etc.). According to R. L. Trask (1994: 16), "English has adopted a possibly surprising way of obtaining new scientific and technical terms. What we do is to borrow words from Latin and Ancient Greek and then combine them into new English words".

T. O. Bergman and G. de Morveau established a programme to check the system of chemical nomenclature, but Lavoisier and his colleagues, especially Berthollet, put it into practice. A remarkable feature of this system is the standardization of the meaning of the suffixes or pairs -ous, -ic and -ite, -ate, already introduced into chemistry, where their use was not delimited. According to the $O E D$., in chemistry, adjectives ending in -ous, from names of elements, denote acids and other compounds with a larger proportion of the 
element in question than those denoted with an adjective ending in -ic; the suffix -ic forms the names of oxygen acids and other compounds with a higher degree of oxidation than those in -ous; the suffix -ite forms, in organic chemistry, the names of some saccharine substances, of glucoses and other organic compounds, apart from explosives, and, in inorganic chemistry, -ite is the ending of the names of the salts of acids denoted by adjectives in -ous, and the suffix -ate denotes salts formed by the action of an acid in a base.

These are some terms ending in -ate (from Latin "-atus"): chlorate ('a salt of chloric acid', from Greek “klorós”, 'green'. 1823: J. Badcock, Domestic Amusements), cryohydrate ( 'a solid hydrate formed by the combination of a salt or other crystalloid with water (ice) at a temperature below freezing-point', combining form of Greek "krúos", 'frost', and French "hydrate", 'a compound of water with another compound or an element'. 1874: F. Guthe in Proceedings of Physical Society) and persulphate ("that sulphate which contains the greatest proportion of oxygen', from Latin "per" and French "sulphat", 'a salt of sulphuric acid'. 1813: T. Thomson, Annals of Philosophy).

Organic compounds ending in -ic (from Latin "-icus") are, for instance, acetic ("of the nature of vinegar', from Latin “acetum”, 'vinegar'. 1808: W. Henry, The Elements of Experimental Chemistry), cupric ('containing copper in chemical combination', from Latin "cuprum", 'copper'. 1799: Davy in Contributions to Physical and Medical Knowledge of Beddoes), ferric ('of, pertaining to, or extracted from iron', from Latin "ferrum", 'iron'. 1799: Davy in Contributions to Physical and Medical Knowledge of Beddoes) and stannic ('of a compound: containing tin as a quadrivalent element', from Latin "stannum", 'tin'. 1790: Kerr, translation of Lavoisier's Elements of Chemistry).

The English chemist Humphry Davy (1778-1829) is one of the scientists that introduced chemical terms into English (e.g. cupric, ferric, antracite, barium, calcium, chloride, chlorine, magnesium, potassium, sodium, etc.). Davy explained very clearly and precisely the relationship between electricity and chemistry, and, although at first he based it on the experimental work of other chemists, he was outstanding in the science of this period. By means of electrical methods he conducted experiments which led to the discovery of sodium, potassium, calcium, strontium, magnesium, barium, boron and many other metals, and chlorine, which is used for bleaching in the textile industry. This name is derived from Greek "klorós", 'green', because of its colour.

Terms ending in -ite (from Latin "-ita”, Greek "-ités") are, for instance, antracite ("the non-bituminous variety of coal', Present-day English anthracite, from Latin "anthracites". 1812: Davy, Elements of Chemical Philosophy), dynamite ('a high explosive prepared from nitro-glycerine mixed with some inert absorptive substance', from Greek "dúnamis", 'force'. 1867: Specifications of Newton's Patent) and stannite ('a salt of stannous acid', from Latin "stannum", 'tin'. 1851: Watts, translation of Gmelin's History of Chemistry).

These are some words ending in -ous (from Latin “-osus, -a, -um”): anhydrous ( having no water in its composition: said of salts, crystals, destitute of water of crystallization, etc.', from Greek "ánudros”, 'waterless'. 1819: Pantologia), ferrous ('a term applied to compounds in which iron combines as a divalent', from Latin "ferrum”, 'iron'. 1865: G. Gore in Orr's Circle of the Sciences) and zincous ('pertaining to or of the nature of zinc', from Latin "zincum", 'zinc'. 1842: T. Graham, Elements of Chemistry). In this kind of formation, the 
shortness and simplicity of terms facilitate the acquisition, retention and transfer of chemical knowledge. As I. de la Cruz Cabanillas (vid. Bernárdez Sanchís et al., 2001: 708) states, "en el periodo del inglés moderno se dispone ya de una amplia gama de afijos: a los afijos nativos y aquellos que se adoptaron del francés durante la etapa del inglés medio se le suman ahora los derivados del latín y del griego".

Lavoisier's successors frequently use Greek roots, specially numeral, e.g. mon-oxide (Present-day English monoxide), di-oxide (Present-day English dioxide), trioxide, tetroxide, pentoxide, etc., although they sometimes form mixed compounds with Latin and Greek roots, e.g. sesqui-oxide (Present-day English sesquioxide).

The evolution of chemical theory in the late $18^{\text {th }} \mathrm{c}$. leads to the formation of new terms which denote gases, elements and newly-discovered chemical products such as acetone ('a colourless limpid liquid related to acetic acid, but containing less oxygen', from Latin “acetum”, 'vinegar', and Greek “-one”. 1858: Thudichum, The Urine), acetylene ('a gaseous hydrocarbon', from Latin "acetum" and Greek "úle”, 'substance', and "-ene". 1864: H. Spencer, Biology), aluminum ( 'a metal, white, sonorous, ductile, and malleable, very light, not oxidized in the air, used for instruments, ornaments, and as an alloy', Present-day English aluminium, -um, from Latin "alumin-, alumen", and "-ium” (Davy, 1807). 1812: Quarterly Review), ammonia ('a colourless gas with pungent smell and strong alkaline reaction', from Latin “ammonia”. 1799: A. Aikin, Syllabus of Lectures of Chemistry) and cyanide ('a simple compound of cyanogen with a metal or an organic radical', from the Greek combining form "kuanos", 'dark blue mineral', and French "-ide". 1826: Henry, Elements of Chemistry). As. F. Katamba (1994: 194) states,

in principle, anything in language can be borrowed. In practice most of the words that are borrowed belong to the open lexical classes (i.e. nouns, verbs, adjectives and adverbs). And of these, nouns top the list, followed by verbs and adjectives. The reason why nouns are the commonest loanwords is not difficult to see. Normally, borrowing takes place because a word is needed to give a name to an unfamiliar animal, thing or cultural phenomenon.

According to R. L. Trask (1994: 16), "borrowing may take place in order to obtain words for genuinely new things, or merely for reasons of prestige".

\section{CONCLUSIONS}

These lists of scientific words show, not only a greater scientific specialization, but also the adoption and adaptation of several lexical elements of Latin and Greek origin in different formations following fixed patterns as in the case of scientific names in cryo- and electro-, -logy and -ics, and chemical adjectives in -ate, -ite, -ic and -ous. Their international nature, shortness, preciseness and easy deduction of their meanings give rise to their widespread use. Because of the richness of Greek and Latin in word-forming elements, many scientific words are formed from them. We must also take into account the poverty of the English language of this period in supplying suitable names for the vast number of newly-discovered or invented objects. 
It is the scientists who usually record for the first time or invent this new scientific terminology. In the first case, we may mention the mathematicians J. Harris in Lexicon Technicum and Emerson in Fluxions. In the second case, a clear example is the English physicist and chemist Michael Faraday in Research in Electricity, where he recorded several electrical terms invented by him, the French chemist Lavoisier, who put into practice the review of the system of chemical nomenclature, and the English chemist Humphry Davy, who is one of the scientists who introduces a large number of chemical terms into English.

\section{REFERENCES}

Bernárdez SAnchís, E., et al. 2001. Lingüística histórica inglesa. Barcelona: Ariel.

Blake, N. F. 1996. A History of the English Language. London: Macmillan.

CRYstal, D. 2003. The Cambridge Encyclopedia of the English Language. Cambridge: CUP.

CulPePER, J. 1997. History of English. London and New York: Routledge.

Görlach, M. 1994. The Linguistic History of English. London: Macmillan. . 1999. English in Nineteenth-Century England: An Introduction. Cambridge: CUP.

Gramley, S. and K. M. Pätzold. 1992. A Survey of Modern English. London and New York: Routledge.

Katamba, F. 1994. English Words. London and New York: Routledge.

Millward, C. M. 1996. A Biography of the English Language. Orlando, Florida: Holt, Rinehart and Winston, Inc.

PÉREZ IgLesias, E. 1998. El inglés científico-técnico: evolución histórica. Salamanca: Hespérides.

Sмiтн, J. J. 1999. Essentials of Early English. London: Routledge.

The Compact Edition of the Oxford English Dictionary. 1971. Oxford: OUP. 3 vols.

The Oxford English Dictionary 1992. Oxford: OUP. CD-ROM.

Trask, R. L. 1994. Language Change. London and New York: Routledge. 